University of Nebraska - Lincoln

DigitalCommons@University of Nebraska - Lincoln

Publications from USDA-ARS / UNL Faculty

U.S. Department of Agriculture: Agricultural

Research Service, Lincoln, Nebraska

$9-14-2017$

\title{
Release of 19 Waxy Winter Wheat Germplasm, with Observations on Their Grain Yield Stability
}

\author{
Robert A. Graybosch \\ USDA-ARS \& University of Nebraska- Lincoln, bob.graybosch@ars.usda.gov \\ P. Stephen Baenziger \\ USDA-ARS \& University of Nebraska- Lincoln, pbaenziger1@unl.edu \\ R. L. Bowden \\ Kansas State University, robert.bowden@ars.usda.gov \\ F. Dowell \\ USDA-ARS-CGAHR-SPIERU, floyd.dowell@usda.gov
}

L. Dykes

USDAARS, NCSL, linda.dykes@usda.gov

See next page for additional authors

Follow this and additional works at: https://digitalcommons.unl.edu/usdaarsfacpub

Graybosch, Robert A.; Baenziger, P. Stephen; Bowden, R. L.; Dowell, F.; Dykes, L.; Jin, Y.; Marshall, D. S.;

Ohm, J.-B.; and Cafe-Treml, M., "Release of 19 Waxy Winter Wheat Germplasm, with Observations on Their Grain Yield Stability" (2017). Publications from USDA-ARS / UNL Faculty. 2334.

https://digitalcommons.unl.edu/usdaarsfacpub/2334

This Article is brought to you for free and open access by the U.S. Department of Agriculture: Agricultural Research Service, Lincoln, Nebraska at DigitalCommons@University of Nebraska - Lincoln. It has been accepted for inclusion in Publications from USDA-ARS / UNL Faculty by an authorized administrator of DigitalCommons@University of Nebraska - Lincoln. 


\section{Authors}

Robert A. Graybosch, P. Stephen Baenziger, R. L. Bowden, F. Dowell, L. Dykes, Y. Jin, D. S. Marshall, J.-B. Ohm, and M. Cafe-Treml 


\title{
Release of 19 Waxy Winter Wheat Germplasm, with Observations on Their Grain Yield Stability
}

\author{
R. A. Graybosch,* P. S. Baenziger, R. L. Bowden, F. Dowell, L. Dykes, Y. Jin, D. S. Marshall, J.-B. Ohm, and M. Caffe-Treml
}

Abstract

"Waxy" wheats (Triticum aestivum L.) produce endosperm starch devoid, or nearly so, of amylose. Waxy starch consists only of amylopectin, imparts unique cooking properties, and serves as an efficient substrate for the production of modified food starches. To expand the genetic variation of waxy wheats useful to Great Plains breeding programs, the USDA-ARS, in cooperation with the University of Nebraska, developed and released 19 waxy winter wheats (Reg. No. GP-1003, PI 677864 to Reg. No. GO-1021, PI 677882). Three of the waxy germplasm lines have soft endosperm texture; the remaining 16 lines have hard-textured grain. The grain yields of six of the waxy winter wheat germplasm lines were not significantly different from the highest yielding nonwaxy cultivar ('Freeman'). All but four waxy germplasm lines had grain yields statistically equal to that of the waxy winter wheat cultivar Mattern. Grain yield stability (or response to changing environments) of the waxy germplasm lines demonstrated similar trends to those of the nonwaxy controls. Grain yield observations and responses to changing production potentials argue against any yield drag associated with waxy starch and indicate potential for the development of additional and competitive cultivars.

Copyright $\odot$ Crop Science Society of America. All rights reserved.

Journal of Plant Registrations 12:152-156 (2018).

doi:10.3198/jpr2017.03.0018crg

Received 29 Mar. 2017.

Accepted 20 June 2017.

Registration by CSSA.

5585 Guilford Rd., Madison, WI 53711 USA

*Corresponding author (bob.graybosch@ars.usda.gov)
$\mathrm{H}$ EXAPLOID WAXY wheats (Triticum aestivum L.) carry three nonfunctional (null) alleles $\left(W_{x}-A 1 b\right.$, $W x-B 1 b$, and $W x-D 1 b)$ at loci encoding the enzyme granule-bound starch synthase (EC 2.4.1.21) and produce endosperm starch nearly devoid of amylose (Nakamura et al., 1995). Waxy wheat starch may be used in the production of modified food starches and in other food and industrial applications (Graybosch, 1998; Van Hung et al., 2006; Graybosch and Hansen, 2016). Waxy flour, when added to typical, wild-type wheat flour, can improve the shelf life of baked goods (Bhattacharya et al., 2002), and amylose-free starch is more efficient in ethanol production than are wild-type (typical) starches (Zhao et al., 2009). Waxy wheat starch can serve as a more efficient substrate for the production of maltodextrins (Maningat et al., 2009). Waxy wheats also may be used to donate one or more waxy null alleles in wheat breeding programs. Evidence suggests the presence of one or more waxy null alleles, conditioning a reduced amylose or "partial waxy" condition, can improve texture and cooking properties of certain Asian noodle products (Epstein et al., 2002). The use of fully waxy lines as parental materials will increase the frequency of partial waxy segregants in derived breeding populations.

The absence of the granule-bound starch synthase eliminates one of the two major pathways in cereal endosperm starch synthesis. As starch represents the most abundant storage component of wheat grain, the question arises as to whether elimination of the granule-bound starch synthase reduces grain yield. Previous work (Graybosch et al., 2003) demonstrated grain yields of spring waxy wheats did not differ from the average grain yield of control cultivars. A secondary objective of the present work was to determine whether this observation held true for winter waxy wheats and whether such wheats differed in grain yield stability over multiple environments.

Waxy wheats were unknown to science until 1995 (Nakamura et al., 1995), and only two waxy wheat cultivars (Morris and King, 2007; Graybosch et al., 2014) have been released in North America

R.A. Graybosch, USDA-ARS, 251 Filley Hall, Univ. of Nebraska-Lincoln, East Campus, Lincoln, NE 68583; P.S. Baenziger, Dep. of Agronomy and Horticulture, 202 Keim Hall, EC, Univ. of Nebraska-Lincoln, Lincoln, NE 68583; R.L. Bowden, USDA-ARS, CGAHR, 4007 Throckmorton Hall, Kansas State Univ., Manhattan, KS 66506; F. Dowell, USDA-ARS-CGAHR-SPIERU, 1515 College Ave., Manhattan, KS 66502; L. Dykes and J.-B. Ohm, USDAARS, NCSL, 1307 18th St. North, Fargo, ND 58102; Y. Jin, USDA-ARS-CDL, 1551 Lindig St., Univ. of Minnesota, St. Paul, MN 55108; D.S. Marshall, USDA-ARS, 3411 Gardner Hall, North Carolina State Univ., Campus Box 7616, Raleigh , NC 27695; M. Caffe-Treml, Agronomy, Horticulture \& Plant Science, Box 2108 South Dakota State Univ., Brookings, SD 57007. 
to date. Only 'Mattern' (Graybosch et al., 2014) is adapted to Great Plains agro-ecological zones. To expand the range of available adapted genetic backgrounds, the USDA-ARS, in cooperation with the University of Nebraska, developed and released 19 Great Plains-adapted waxy winter wheat germplasm lines (Reg. No. GP-1003, PI 677864 to Reg. No. GP-1021, PI 677882).

\section{Methods}

Pedigrees, PI numbers, and USDA National Plant Germplasm System registration numbers of the 19 waxy winter wheat germplasm lines are listed in Table 1. Lines were developed via several rounds of phenotypic recurrent selection, commencing with Asian and North American donor lines of the $W x$ null alleles and passing through a series of winter-hardy, but lower-yielding waxy experimental lines developed by the USDA-ARS. The following parental lines were all waxy wheat breeding lines developed by the USDA-ARS at Lincoln, NE: 99 waxy bulk, NX04Y2066, 99Y1445, NX04Y2090, and NX03Y2115. The 99 waxy bulk population was an accidental mix of waxy wheats derived from the following crosses: VA94-5225/'Norin 67' (PI 235238)//'BaiHuo', 'Cimarron'/'RioBlanco'// BaiHuo/'TAM200', Cimarron/TAM200//BaiHuo, Cimarron/TX93V5922//K94H115/BaiHuo, A92-3327//'Ike'/3/ BaiHuo/KY88C-435-9, and BaiHuo/KY88C-435-9//Ike. NX04Y2066 was derived from N95L1229 (PI 608032)/99Y1442 (BaiHuo/'Kanto107'//Ike/3/96MD7413-10); 99Y1445 was selected from BaiHuo/Kanto107//Ike/3/96MD7413-10; NX04Y2090 was derived from a cross between 99Y1443 (BaiHuo/ Kanto107//Ike/3/96MD7413-6) and SD97063 (ND8889/ NE90574); NX03Y2115 was descended from (Cimarron/RioBlanco)//(BaiHuo/L910145)/3/('Colt'/'Cody')//('Stozher'/ NE86582). Donors of the $W x$ null alleles in the above pedigrees included Cimarron ( $w x-A 1$ null), RioBlanco and TAM200 ( $w x-B 1$ null), BaiHuo ( $w x-D 1$ null), and Ike ( $w x-A 1$ and $w x-B 1$ nulls) (Graybosch et al., 1998). Additional parents (nonwaxy) used in the final mating cycles included 92201D5-2-29, a soft winter wheat breeding line developed by Purdue University; NI03418, a hard red winter wheat breeding line developed by the University of Nebraska-Lincoln; 'Wesley', a hard red winter wheat cultivar jointly developed by USDA-ARS and the University of Nebraska-Lincoln (Peterson et al., 2001); 'NuHorizon'(PVP 200100217), a hard white winter wheat cultivar developed by Monsanto; and 'NuDakota' (PVP 200600235), a hard white winter wheat cultivar developed by Syngenta Seeds.

The final cross of each pedigree was conducted in 2006. Populations were advanced, in-bulk, until the $\mathrm{F}_{3}$ generation. A bulk sample of $\mathrm{F}_{4}$ seed was then rapidly phenotyped using a singlekernel sorting device affixed with near-infrared reflectance (NIR) technology (Dowell et al., 2009) that facilitated identification of waxy seed and allowed development of $>95 \%$ waxy $\mathrm{F}_{4}$ seed samples. $\mathrm{F}_{4}$ seed was used to plant bulk populations in fall 2009 at the University of Nebraska Agricultural Research and Development Center near Mead, NE. The following summer, single head selections were made from visually selected populations. A few seeds were removed from each head and stained with a dilute solution of $\mathrm{I}_{2} \mathrm{KI}\left(5 \mathrm{~g} \mathrm{KI}+0.5 \mathrm{~g} \mathrm{I}_{2}\right.$ in $250 \mathrm{~mL} \mathrm{H}_{2} \mathrm{O}$, diluted $1: 10$ with $\mathrm{H}_{2} \mathrm{O}$ before each use) which differentiates waxy and nonwaxy kernels (Fig. 1). Verified waxy selections were seeded at Mead, NE, as single 1 - $m$ head rows, and selections made on disease resistance and agronomic properties in 2011. Single heads were obtained from each selected row, a few seed of each stained with $\mathrm{I}_{2} \mathrm{KI}$, and remaining seed planted in single $2.5-\mathrm{m}$ rows at Yuma, AZ. Yuma rows were each harvested in-bulk, and the resultant $\mathrm{F}_{5}$-derived lines were assigned selection numbers. Forty-eight waxy winter wheat experimental lines were subsequently evaluated in multilocation replicated yield trials. Replicated trials were harvested from Mead, NE, and Aurora, SD, in 2013, and from Lincoln, Mead, Clay Center, North Platte, and Sidney, NE in 2014. The 48 waxy entries were planted along with control cultivars, 'Freeman', 'McGill', 'Infinity CL', 'Goodstreak', 'Overland', 'Camelot', 'Millennium', 'Settler CL', Mattern (waxy), 'Robidoux', and 'Pronghorn', and the breeding line NI08708. At each location, entries were seeded in four-row plots, trimmed to $3 \mathrm{~m}^{2}$ before harvest, with three field replications (at Nebraska locations) using a randomized complete block design.

Table 1. Nineteen waxy wheat germplasm and pedigrees.

\begin{tabular}{|c|c|c|c|}
\hline PIno. & Registration no. & Entry & $\begin{array}{l}\text { Pedigree } \\
\end{array}$ \\
\hline PI 677864 & GP-1003 & NX12Y8174 & 92201D5-2-29/99 waxy bulk//NI03418 \\
\hline PI 677865 & GP-1004 & NX12Y8175 & 92201D5-2-29/99 waxy bulk//NI03418 \\
\hline PI 677866 & GP-1005 & NX12Y8176 & 92201D5-2-29/99 waxy bulk//NI03418 \\
\hline PI 677867 & GP-1006 & NX12Y8178 & 92201D5-2-29/99 waxy bulk//NI03418 \\
\hline PI 677868 & GP-1007 & NX12Y8186 & NX04Y2066/Wesley//99Y1445/NuHorizon \\
\hline PI 677869 & GP-1008 & NX12Y8187 & NX04Y2066/Wesley//99Y1445/NuHorizon \\
\hline PI 677870 & GP-1009 & NX12Y8188 & NX04Y2066/Wesley//99Y1445/NuHorizon \\
\hline PI 677871 & GP-1010 & NX12Y8189 & NX04Y2066/Wesley//99Y1445/NuHorizon \\
\hline PI 677872 & GP-1011 & NX12Y8190 & NX04Y2066/Wesley//99Y1445/NuHorizon \\
\hline PI 677873 & GP-1012 & NX12Y8205 & NX04Y2066/Wesley//99Y1445/NuHorizon \\
\hline PI 677874 & GP-1013 & NX12Y8209 & NX04Y2066/Wesley//99Y1445/NuHorizon \\
\hline PI 677875 & GP-1014 & NX12Y8210 & NX04Y2066/Wesley//99Y1445/NuHorizon \\
\hline PI 677876 & GP-1015 & NX12Y8212 & NX04Y2066/Wesley//99Y1445/NuHorizon \\
\hline PI 677877 & GP-1016 & NX12Y8213 & NX04Y2066/Wesley//99Y1445/NuHorizon \\
\hline PI 677878 & GP-1017 & NX12Y8214 & NX04Y2066/Wesley//99Y1445/NuHorizon \\
\hline PI 677879 & GP-1018 & NX12Y8215 & NX04Y2066/Wesley//99Y1445/NuHorizon \\
\hline PI 677880 & GP-1019 & NX12Y8221 & NuDakota//NX04Y2090/NX03Y2115 \\
\hline PI 677881 & GP-1020 & NX12Y8222 & NuDakota//NX04Y2090/NX03Y2115 \\
\hline PI 677882 & GP-1021 & NX12Y8223 & NuDakota//NX04Y2090/NX03Y2115 \\
\hline
\end{tabular}




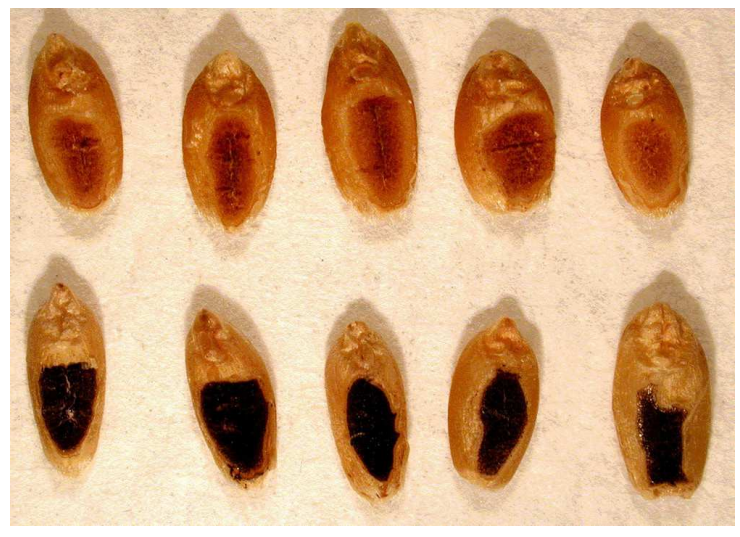

Fig. 1. Endosperm of waxy and wild-type wheat stained with $\mathrm{I}_{2} \mathrm{KI}$. Waxy wheat kernels stain reddish-brown; wild-type kernels stain blue-black.

At Aurora, SD, entries were seeded in seven-row plots, trimmed to $6 \mathrm{~m}^{2}$ before harvest, with two replications. The 19 waxy winter wheats described herein were selected from this larger sample of 48 breeding lines on the basis of field performance and purity of waxy seed. Experiment-wide LSD (0.05) values and means were calculated using all entries and are reported herein. Regression analysis (Eberhart and Russell, 1966) was used to evaluate grain yield stability across environments. Grain yields of each entry were used as dependent variables, and the average grain yield of all entries at each location was used as the independent variable (environmental index). Slopes ( $b$ values) of all entries were evaluated for statistical identity to that of McGill, the control cultivar with the highest $b$ value (see below). Subsequent to harvest, the samples from Mead 2013 and 2014 were evaluated for grain and quality traits as per Graybosch et al. (2016). Disease responses were evaluated via the USDA-ARS coordinated 2016 Regional Germplasm Observation Nursery (USDA-ARS, 2016).

\section{Characteristics}

Grain yields, obtained from replicated yield trials in seven Nebraska and South Dakota environments over the 2013 and 2014 growing seasons, are presented in Table 2 . The grain yields

Table 2. Mean grain yield, grain volume weight, and results of regressiont of 19 waxy winter wheat lines (NX12Y8xxx) and control cultivars from seven Great Plains environments, 2013-2014.

\begin{tabular}{|c|c|c|c|c|c|}
\hline Entry & Grain yield & Grain volume weight & $R^{2}$ regression & Slope (b) & P, slope vs. McGill slope \\
\hline & $\mathrm{kg} \mathrm{ha}^{-1}$ & $\mathrm{~kg} \mathrm{hL}^{-1}$ & & & \\
\hline Freeman & 4728 & 76.5 & 0.81 & 1.13 & 0.611 \\
\hline McGill & 4698 & 78.9 & 0.98 & 1.26 & \\
\hline Infinity CL & 4663 & 79.1 & 0.94 & 1.11 & 0.328 \\
\hline Goodstreak & 4652 & 79.4 & 0.88 & 1.22 & 0.875 \\
\hline NX12Y8223 & 4644 & 76.0 & 0.89 & 1.03 & 0.200 \\
\hline Overland & 4614 & 78.7 & 0.88 & 0.99 & 0.140 \\
\hline NX12Y8187 & 4561 & 77.0 & 0.98 & 1.22 & 0.776 \\
\hline NW07505 & 4528 & 77.8 & 0.95 & 1.03 & 0.089 \\
\hline Camelot & 4515 & 78.3 & 0.89 & 1.19 & 0.733 \\
\hline NX12Y8189 & 4479 & 75.3 & 0.94 & 1.33 & 0.659 \\
\hline NX12Y8188 & 4457 & 77.0 & 0.95 & 1.22 & 0.785 \\
\hline NX12Y8221 & 4426 & 76.8 & 0.99 & 1.06 & 0.033 \\
\hline NX12Y8222 & 4412 & 75.4 & 0.91 & 1.00 & 0.118 \\
\hline NX12Y8215 & 4411 & 74.8 & 0.83 & 0.96 & 0.159 \\
\hline NX12Y8190 & 4391 & 76.1 & 0.96 & 1.09 & 0.167 \\
\hline Millennium & 4390 & 78.6 & 0.87 & 1.13 & 0.549 \\
\hline Settler CL & 4377 & 77.2 & 0.91 & 1.06 & 0.232 \\
\hline Mattern (waxy) & 4313 & 76.4 & 0.76 & 1.14 & 0.708 \\
\hline Robidoux & 4307 & 76.5 & 0.80 & 1.00 & 0.275 \\
\hline NX12Y8213 & 4294 & 74.0 & 0.96 & 1.02 & 0.051 \\
\hline NI08708 & 4262 & 77.1 & 0.88 & 1.12 & 0.495 \\
\hline NX12Y8209 & 4232 & 75.7 & 0.94 & 0.83 & 0.001 \\
\hline NX12Y8214 & 4224 & 74.4 & 0.87 & 0.78 & 0.002 \\
\hline NX12Y8205 & 4217 & 74.8 & 0.97 & 1.02 & 0.035 \\
\hline Pronghorn & 4208 & 80.8 & 0.70 & 0.80 & 0.066 \\
\hline NX12Y8212 & 4197 & 73.9 & 0.89 & 0.84 & 0.006 \\
\hline NX12Y8210 & 4169 & 75.7 & 0.71 & 0.69 & 0.001 \\
\hline NX12Y8186 & 4157 & 74.5 & 0.88 & 1.28 & 0.775 \\
\hline NX12Y8174 & 3967 & 74.3 & 0.91 & 0.99 & 0.094 \\
\hline NX12Y8178 & 3958 & 71.5 & 0.82 & 1.03 & 0.320 \\
\hline NX12Y8175 & 3932 & 72.0 & 0.88 & 1.03 & 0.222 \\
\hline NX12Y8176 & 3805 & 73.0 & 0.69 & 0.80 & 0.078 \\
\hline Experiment mean & 4027 & 75.3 & & & \\
\hline LSD & 306 & 1.5 & & & \\
\hline
\end{tabular}

† Regression of per location means of each entry against mean location mean (environmental index) of all trial entries. 
of six of the waxy winter wheat germplasm lines were not significantly different from the highest-yielding nonwaxy cultivar (Freeman). All but four waxy germplasm lines had grain yields statistically equal to that of the waxy winter wheat cultivar Mattern. Grain volume weights were reduced in most waxy lines relative to nonwaxy controls. Grain volume weights of McGill and

Table 3. Mean grain yields of the five highest-yielding waxy wheat lines (NX12Y8xxx), based on overall results, compared with five high-yielding nonwaxy cultivars.

\begin{tabular}{|c|c|c|c|c|c|c|c|}
\hline \multirow{2}{*}{ Entry } & \multicolumn{2}{|c|}{2013} & \multicolumn{5}{|c|}{2014} \\
\hline & Mead & Aurora & Clay Center & Lincoln & Mead & North Plate & Sidney \\
\hline & & & & $\mathrm{kg} \mathrm{ha}^{-1}$ & & & - \\
\hline Freeman & 6752 & 4391 & 3470 & 4951 & 5914 & 3467 & 3688 \\
\hline McGill & 6792 & 4657 & 3524 & 4139 & 5979 & 3152 & 4600 \\
\hline Infinity CL & 6083 & 4371 & 3714 & 4482 & 6287 & 3040 & 4521 \\
\hline Goodstreak & 6129 & 4966 & 3494 & 4458 & 6471 & 2755 & 4269 \\
\hline Overland & 6182 & 4102 & 3986 & 4668 & 5778 & 3055 & 4233 \\
\hline NX12Y8223 & 5895 & 4085 & 3674 & 4511 & 6352 & 3365 & 4336 \\
\hline NX12Y8187 & 6694 & 4227 & 3628 & 3816 & 5764 & 3097 & 4604 \\
\hline NX12Y8189 & 6781 & 3578 & 3426 & 4350 & 5655 & 2689 & 4621 \\
\hline NX12Y8188 & 6312 & 3561 & 3334 & 4272 & 5738 & 2877 & 4883 \\
\hline NX12Y8221 & 6038 & 4395 & 3403 & 4136 & 5601 & 3002 & 4387 \\
\hline Experiment mean & 5594 & 3798 & 3051 & 3654 & 5119 & 2804 & 4158 \\
\hline LSD (0.05) & 887 & 605 & 417 & 1218 & 778 & 491 & 782 \\
\hline
\end{tabular}

Table 4. Select grain and flour hardness characteristics of waxy wheat and nonwaxy wheat cultivars and breeding lines.

\begin{tabular}{|c|c|c|c|c|c|c|c|}
\hline Entry & Grain hardness & Grain protein & Flour yield & Flour protein & $\begin{array}{l}\text { Mixograph mix } \\
\text { time }\end{array}$ & $\begin{array}{c}\text { Mixograph } \\
\text { tolerance }\end{array}$ & Gluten index \\
\hline & hardness units & & $-\mathrm{g} \mathrm{kg}^{-1}-$ & & $\min$ & $\mathrm{mm}$ & $\mathrm{g} \mathrm{kg}^{-1}$ \\
\hline Camelot & 67.8 & 127.4 & 625.2 & 113.9 & 8.1 & 11.9 & 966.6 \\
\hline Freeman & 75.7 & 122.0 & 638.3 & 106.8 & 16.8 & 6.0 & 987.1 \\
\hline Goodstreak & 58.9 & 129.6 & 670.6 & 119.1 & 4.7 & 8.8 & 683.3 \\
\hline Infinity CL & 63.3 & 119.7 & 639.3 & 104.9 & 14.3 & 8.9 & 988.8 \\
\hline Mattern & 67.9 & 127.6 & 552.1 & 113.5 & 3.8 & 9.0 & 853.1 \\
\hline McGill & 60.6 & 118.9 & 645.5 & 104.1 & 11.8 & 6.2 & 972.3 \\
\hline Millennium & 65.8 & 126.9 & 664.8 & 112.0 & 6.8 & 10.9 & 941.1 \\
\hline N108708 & 55.6 & 129.0 & 653.9 & 114.9 & 8.0 & 8.8 & 942.6 \\
\hline NW07505 & 72.8 & 124.7 & 620.0 & 109.1 & 13.6 & 10.9 & 990.1 \\
\hline NX12Y8174 & 38.9 & 118.1 & 510.8 & 107.9 & 2.5 & 3.6 & 610.3 \\
\hline NX12Y8175 & 38.3 & 124.0 & 519.8 & 114.0 & 4.1 & 10.3 & 770.8 \\
\hline NX12Y8176 & 57.2 & 120.9 & 606.3 & 113.8 & 3.9 & 8.5 & 820.7 \\
\hline NX12Y8178 & 25.5 & 126.0 & 455.8 & 112.6 & 4.3 & 10.9 & 900.2 \\
\hline NX12Y8186 & 70.0 & 133.4 & 542.0 & 121.8 & 3.2 & 9.0 & 815.5 \\
\hline NX12Y8187 & 62.7 & 124.6 & 609.0 & 113.7 & 9.6 & 20.9 & 803.5 \\
\hline NX12Y8188 & 64.8 & 130.2 & 593.1 & 118.3 & 8.4 & 21.1 & 946.0 \\
\hline NX12Y8189 & 61.2 & 132.4 & 617.9 & 120.0 & 8.3 & 22.6 & 957.5 \\
\hline NX12Y8190 & 65.7 & 123.1 & 601.6 & 111.9 & 9.4 & 22.3 & 931.4 \\
\hline NX12Y8205 & 50.8 & 126.3 & 610.8 & 116.1 & 5.6 & 14.0 & 911.8 \\
\hline NX12Y8209 & 52.1 & 128.4 & 609.3 & 117.3 & 5.4 & 14.3 & 927.7 \\
\hline NX12Y8210 & 56.2 & 132.0 & 599.9 & 121.4 & 10.1 & 21.4 & 944.9 \\
\hline NX12Y8212 & 54.7 & 131.9 & 611.8 & 120.8 & 5.3 & 13.4 & 898.5 \\
\hline NX12Y8213 & 51.7 & 126.1 & 603.3 & 115.8 & 5.2 & 14.9 & 916.3 \\
\hline NX12Y8214 & 50.9 & 125.5 & 599.9 & 114.5 & 5.7 & 14.4 & 929.5 \\
\hline NX12Y8215 & 55.7 & 121.7 & 612.6 & 112.0 & 6.8 & 18.9 & 945.5 \\
\hline NX12Y8221 & 63.3 & 122.7 & 597.6 & 112.7 & 4.6 & 10.9 & 810.5 \\
\hline NX12Y8222 & 66.2 & 125.1 & 593.8 & 116.8 & 4.3 & 12.6 & 867.7 \\
\hline NX12Y8223 & 64.1 & 122.6 & 607.5 & 113.9 & 4.3 & 11.1 & 836.4 \\
\hline Overland & 67.1 & 126.3 & 666.6 & 109.5 & 4.9 & 8.2 & 751.1 \\
\hline Pronghorn & 61.3 & 133.1 & 653.3 & 117.6 & 13.2 & 12.4 & 989.8 \\
\hline Robidoux & 58.9 & 121.1 & 640.7 & 108.1 & 14.5 & 8.4 & 965.6 \\
\hline Settler CL & 62.6 & 125.5 & 662.1 & 111.3 & 13.4 & 9.1 & 992.2 \\
\hline Experiment mean & 59.2 & 127 & 600 & 116 & 6.8 & 11.9 & 888.0 \\
\hline $\operatorname{LSD}(0.05)$ & 2.6 & 6.0 & 15.0 & 6.0 & 1.9 & 4.0 & 84.0 \\
\hline
\end{tabular}


Pronghorn, the two highest observed in the nonwaxy controls, were statistically greater than the largest grain volume weights achieved by any of the waxy germplasm lines. Grain yield stability (or response to changing environments) of the waxy germplasm lines demonstrated (Table 2) similar trends to those of the nonwaxy controls. All waxy germplasm lines had slopes that differed from zero and increased with increases in the environmental index (mean location grain yield). Twelve of the waxy germplasm lines demonstrated slopes ( $b$ values) not significantly different from that of McGill, the control with the highest observed $b$ value. In each environment, at least one of the five highest-yielding waxy wheats, based on grand means, did not differ significantly from the highest-yielding nonwaxy cultivar (Table 3). Grain yield observations and responses to changing production potentials argue against any yield drag associated with waxy (amylose-free) starch and indicate potential for development of additional and competitive cultivars.

Grain and flour quality evaluations from samples grown in two Nebraska production environments indicated a wide range of grain hardness and protein characteristics among the waxy wheat germplasm (Table 4). Based on assessment by a Perten (Hägersten, Sweden) single kernel characterization system, mean hardness scores identified three (NX12Y8174, NX12Y8175, and NX12Y8178) soft endosperm-textured (hardness units < 50) wheats, while the remaining 16 waxy wheats were classified as hard wheats. All of these waxy wheats breed true for red grain color. Gluten protein properties were extremely variable, with mixograph mix times ranging from 2.5 to $10.1 \mathrm{~min}$. The only obvious quality deficiency of the waxy germplasm lines was that all had reduced flour yields relative to the nonwaxy controls. This effect seems to be universal among waxy wheats and was also observed in spring waxy types (Graybosch et al., 2003).

Based on observations from the 2016 USDA-ARS Regional Germplasm Observation Nursery, lines NX12Y8205, NX12Y8209, NX12Y8212, and NX12Y8213 demonstrated at least moderate resistance to KS and NC field races of stripe (yellow) rust (Puccinia striiformis Westend). Resistance genes to stem rust (Puccinia graminis Pers.:Pers. f. sp. tritici Erikss. \& E. Henning) occur in NX12Y8186, NX12Y8187, NX12Y8188, NX12Y8189, and NX12Y8190 (all Srl1) and in NX12Y8205 and NX12Y8209 (Sr7a). No resistance was detected to Ug99 forms of stem rust.

\section{Availability}

Seed of all 19 waxy wheat germplasm lines has been deposited in the USDA National Plant Germplasm System, where it is available immediately. Until the end of calendar year 2018, small quantities of seed also will be available from R. Graybosch,
USDA-ARS, University of Nebraska, Lincoln, NE, 68583. It is requested that the source of this material be acknowledged in future usage by wheat breeding and genetics programs.

\section{References}

Bhattacharya, M., S.V. Erazo-Castrejón, D.C. Doehlert, and M.C. McMullen. 2002. Staling of bread as affected by waxy wheat flour blends. Cereal Chem. 79:178-182. doi:10.1094/CCHEM.2002.79.2.178

Dowell, F.E., E.B. Maghirang, R.A. Graybosch, W.A. Berzonsky, and S.R. Delwiche. 2009. Selecting and sorting waxy wheat kernels using nearinfrared spectroscopy. Cereal Chem. 86:251-255. doi:10.1094/CCHEM86-3-0251

Eberhart, S.T., and W.A. Russell. 1966. Stability parameters for comparing varieties. Crop Sci. 6:36-40. doi:10.2135/cropsci1966.0011183X00060 $0010011 \mathrm{x}$

Epstein, J., C.F. Morris, and K.C. Huber. 2002. Instrumental texture of white salted noodles prepared from recombinant inbred lines of wheat differing in the three granule bound starch synthase (waxy) genes. J. Cereal Sci. 35:51-63. doi:10.1006/jcrs.2001.0412

Graybosch, R.A. 1998. Waxy wheats: Origin, properties, and prospects. Trends Food Sci. Technol. 9:135-142. doi:10.1016/S0924-2244(98)00034-X

Graybosch, R.A., P.S. Baenziger, D.K. Santra, T. Regassa, Y. Jin, J. Kolmer, S. Wegulo, G. Bai, P. St. Amand, X. Chen, B. Seabourn, F. Dowell, R. Bowden, and D.M. Marshall. 2014. Registration of 'Mattern' waxy (amylose-free) winter wheat. J. Plant Reg. 8:43-48. doi:10.3198/jpr2013.08.0045crc

Graybosch, R.A., and L.E. Hansen. 2016. Functionality of chemically modified waxy, partial waxy and wild-type starches from common wheat. Starke 68:496-504. doi:10.1002/star.201500241

Graybosch, R.A., J. Ohm, and L. Dykes. 2016. Observations on the quality characteristics of waxy (amylose-free) winter wheats. Cereal Chem. 93:599-604. doi:10.1094/CCHEM-02-16-0021-R

Graybosch, R.A., C.J. Peterson, L.E. Hansen, S. Rahman, A. Hill, and J. Skerritt. 1998. Identification and characterization of U.S. wheats carrying null alleles at the $w x$ loci. Cereal Chem. 75:162-165. doi:10.1094/ CCHEM.1998.75.1.162

Graybosch, R.A., E. Souza, W. Berzonsky, P.S. Baenziger, and O.K. Chung. 2003. Functional properties of waxy wheat flours: Genotypic and environmental effects. J. Cereal Sci. 38:69-76. doi:10.1016/S0733-5210(02)00139$\mathrm{X}$

Maningat, C.C., P.A. Seib, S.D. Bassi, K.S. Woo, and G.D. Lasater. 2009. Wheat starch: Production, properties, modification, and uses. In: N. BeMiller and R.L. Whistler, editors, Starch chemistry and technology. Academic Press, New York. p. 441-510.

Morris, C.F., and G.E. King. 2007. Registration of 'Waxy-Pen' soft white spring waxy wheat. J. Plant Reg. 1:23-24. doi:10.3198/jpr2006.08.0551crc

Nakamura, T., M. Yamamori, H. Hirano, S. Hidaka, and T. Nagamine. 1995. Production of waxy (amylose-free) wheats. Mol. Gen. Genet. 248:253-259. doi:10.1007/BF02191591

Peterson, C.J., D.R. Shelton, P.S. Baenziger, D.D. Baltensperger, R.A. Graybosch, W.D. Worrall, L.A. Nelson, D.V. McVey, J.E. Watkins, and J. Krall. 2001. Registration of 'Wesley' wheat. Crop Sci. 41:260-261. doi:10.2135/ cropsci2001.411260-ax

USDA-ARS. 2016. 2016 regional performance nursery. https://www.ars.usda. gov/plains-area/lincoln-ne/wheat-sorghum-and-forage-research/docs/ hard-winter-wheat-regional-nursery-program/research/.

Van Hung, P.V., T. Maeda, and N. Morita. 2006. Waxy and high-amylose wheats- Characteristics, functionality and uses. Trends Food Sci. Technol. 17:448-456. doi:10.1016/j.tifs.2005.12.006

Zhao, R., X. Wu, B.W. Seabourn, S.R. Bean, L. Guan, Y. Shi, J.D. Wilson, R. $\mathrm{Madl}$, and D. Wang. 2009. Comparison of waxy vs. nonwaxy wheats in fuel ethanol fermentation. Cereal Chem. 86:145-156. doi:10.1094/CCHEM86-2-0145 